\title{
New investigations of Upper Devonian wood from the north of the European part of Russia
}

\author{
ANNA LYUBAROVA ${ }^{1,2^{*}}$ and SERGEY M. SNIGIREVSKY ${ }^{2,1}$ \\ ${ }^{1}$ Komarov Botanical Institute, Russian Academy of Sciences; 2 Prof. Popov Street, St. Petersburg, 197376, \\ Russia; e-mail: lyubarova.anna@gmail.com \\ ${ }^{2}$ Institute of Earth Sciences, St. Petersburg State University; Vassil'evsky Island, 16 Linia, 29, \\ St. Petersburg, 199178, Russia; e-mails: s.snigirevsky@spbu.ru, s.snig@mail.ru
}

Received 16 September 2019; accepted for publication 7 April 2020

\begin{abstract}
The paper describes a continuation of our research on the distribution of archaeopteridalean plants in the north of the European part of the Russian Federation. New data on archaeopterid wood remains from Upper Devonian deposits of Northern Timan are presented. Representatives of the genus Callixylon are documented: the type species C. trifilievii, fragments of stumps (or root systems) with C. zalesskyi wood, and a small branch of $C$. sp.
\end{abstract}

KEYWORDS: fossil wood, Callixylon, secondary xylem, Devonian, Archaeopterid forests, Northern Timan

\section{INTRODUCTION}

Palaeozoic sediments of the north of the European part of Russia are rather poorly studied palaeontologically. All the information about Devonian and Early Carboniferous wood from this region are rare and have not been the subject of detailed systematic studies. Previously we reported on finds of Devonian woods Callixylon trifilievii Zalessky from sections of Andoma Mt. at Onega Lake (Snigirevskaya and Snigirevsky, 2001). In the same article we noted the presence of Late Devonian plant remains from the Lovozero Massif in the Kola Peninsula, from the Zimniy Bereg (= winter coast) of the White Sea, and from Northern Timan. Data on the Lovozero Massif flora is contained in the work of A.N. Kryshtofovich (1937); finds of fossil plant remains were secondarily reported by N.M. Petrosjan (Bussen et al., 1969), who determined Chakassiophyton krasnovii Ananiev from Middle Devonian volcanogenic deposits.

Since 2001 a number of works on anatomically preserved remains from this region, and

Corresponding author their relation to Late Devonian and Early Carboniferous forests communities, have been published. In the Arkhangelsk region (north of Arkhangelsk city), Lower Carboniferous deposits were established after finding Palaeoxylon bourbachensis Coulon et Lemoigne (Antashtchuk and Snigirevsky, 2003: p. 94, 96-100, figs $2 \mathrm{a}-\mathrm{e}$ ), which was first described from the Upper Viséan of Vosges (Coulon and Lemoigne, 1969), and the probable identity between P. bourbachensis and Pitus withamii was reported by Galtier et al. (1998). A rich complex of lycophytes and Lyginopteridales with rare equisetalean stems was found within the Belomorsko-Kuloyskoye Plateau (Lake Tovskoye) and described by O.A. Orlova (2007; Orlova et al., 2004). Also, rather peculiar wood presumably related to Lyginopteridophyta (?) Tovoxylon alekseevii - was described (Orlova, 2009: p. 98-101, pl. 14, figs 1-5).

The work of N.S. Snigirevskaya (2012) was devoted to the study of detrital plant fragments from the vents of volcanic pipes of kimberlite rocks. In that paper she described 
Callixylon timanicum Zalessky ex Lemoigne et al. (Snigirevskaya, 2012: p. 1464, 1465: pl. I) and Nematosketum diversiforme Burgess et Edwards (Snigirevskaya, 2012: p. 1465-1467: pl. II), previously defined by us as Callixylon sp. and Nematophytales gen. indet. (Snigirevskaya and Snigirevsky, 2001: p. 101).

From Frasnian deposits of Middle Timan (Riv. Tsil'ma, Ust 'Chirka Formation), Orlova and colleagues (2011) described pyritized wood of Callixylon trifilievii with a well-preserved branch scar, studied by scanning electron microscopy.

One of the taxonomically richest regions in the north of the European part of Russia (Arctic zone along the coast of the Barents Sea) is Northern Timan. Lists of fossil plants from the Upper Devonian of Northern Timan are given in Orlova et al. (2016).

Despite the abundance of adpressions and petrifications with excellent morphological preservation, and the ability to study reproductive organs located in situ in the sporangia of ancient plants (Snigirevsky et al., 2007), fossil wood from these sections has not been studied. There is only one publication devoted to the anatomical structure of Pietzschia timanica Lepechina (1968: p. 38-40, pl. 14, figs 1-5), which was excluded from this genus by Soria and Meyer-Berthaud (2005) because of the probable relation of that material to Xenocladia medullosina Arnold.

Prior to our studies, Devonian sections of Northern Timan were visited by the palaeobotanist A.L. Jurina only once, during a one-day geological excursion in 1979. She collected several samples, subsequently transferred to N.S. Snigirevskaya for study (Snigirevskaya Collection, Komarov Botanical Institute, KBI, No. 1501); some thin sections were transferred to $Y$. Lemoigne (France). These samples were identified by Snigirevskaya in 1980 as Callixylon timanicum. In a revision of the genus Callixylon (Lemoigne et al., 1983: p. 50) a new combination was proposed, Callixylon (Dadoxylon) timanicum, without an author's attribution of the species and combination. Considering that the species was named by Zalessky and described in detail in "Revision...", the correct spelling of the combination should have read C. timanicum Zalessky ex Lemoigne, Iurina et Snigirevskaya, 1983. The authors of "Revision..." proposed to refer this species to $C$. trifilievii and considered C. timanicum to be its junior synonym for the type species. Probably this situation is almost unique in the palaeobotanical literature, when a new combination was presented and this name was moved to synonymy.

Since 1993 (by SMS) and since 2016 together with P.A. Beznosov (Institute of Geology, Komi branch of RAS, Syktyvkar), field work has been carried out in fossiliferous Upper Devonian sediments on the slopes of Timan Ridge (Sula River, Volonga and its tributaries, Belaya, etc.) and along the coast of Chesha Bay of the Barents Sea. A number of publications are devoted to the study of morphologically preserved plant remains (Snigirevsky, 1997; see bibliography in Orlova et al., 2016); the remains of vertebrate animals were studied by Beznosov (Beznosov, 2018; Beznosov et al., 2014, 2017, 2018b). Our research is mainly aimed at reconstructing the palaeoecological settings of the Late Devonian in Northern Timan and making a detailed study of the features of the first forest ecosystems, which became the main biotope in which the development of the first land vertebrates became possible (Beznosov et al., 2018a).

According to the results of an expedition of the A.P. Karpinsky Russian Geological Research Institute (VSEGEI, St. Petersburg) in 2018, the Upper Devonian sediments of the Kanin Peninsula in its southeast part were characterized palaeontologically for the first time. Numerous remains of Archaeopteris fissilis Schmalhausen of Frasnian age were found in almost all studied sections. Obviously, these plants were dominant in the Late Devonian plant communities of this territory. In addition, large fragments of picnoxylic wood were found in coastal-marine Upper Devonian sediments discovered along the banks of the Murseyyakha River. This material is briefly described in this article.

\section{MATERIALS AND METHODS}

The wood from the Devonian deposits of North Timan is in various states of preservation. There are large axes with pith and massive secondary wood, and scattered split fragments with anatomical preservation. Thin sections were made of the most complete specimens; all the material was pre-impregnated with epoxy resin. Fragile and small samples were studied exclusively by electron microscopy. The wood fragments are pyritized and coalified. Often there are samples shaped like the original wood which have passed into the anthracite stage or are mineralized without preservation of the anatomy. 
The sections were made in the Laboratory of Sample Preparation and Sample Processing of the Institute of Earth Sciences, St. Petersburg State University (M.V. Nikitina and T.O. Krasyukova). Images were made with Leica M205C and Keyence VHX 1000 microscopes (RC X-ray diffraction methods, SPbSU). Wood surface microstructure was scanned using a Hitachi TM3000 desktop scanning electron microscope-microanalyzer (RC Microscopy and Microanalysis, SPbSU).

The studied wood comes from sediments of different origin and age (Fig. 1):

- Kumushka Formation, Lower Frasnian: in interbasalt interlayers and coal lenses (E slope of Northern Timan, Sula River at Padun waterfall) - Callixylon sp. (sample PM-SPbSU-89-9);

- Grubyj Ruchey Formation, Lower Frasnian: in coastal-marine terrigenous sediments (E slope of Northern Timan, Sula River at Padun waterfall) Callixylon trifilievii (sample PM-SPbSU-89-1, PMSPbSU-89-9), Callixylon sp. (sample PM-SPbSU-89-3);

- Tayaokuyakha Formation, Lower Frasnian: in terrigenous sediments represented by interbedding of thin (less than $2 \mathrm{~m}$ thick) interlayers of conglomerates, sandstones and siltstones (Kanin Peninsula, Murseyyakha River) - Callixylon sp. (sample PMSPbSU-96-1, PM-SPbSU-96-86);
- Ust'e Bezmoshitsa Formation, Upper Frasnian: in terrigenous sediments of a complex of deltaic sandstones, siltstones and clays (W slope of Northern Timan, middle course of Volonga River, E coast of Chesha Bay of Barents Sea) Callixylon sp. (samples PM-SPbSU-88-16, PM-SPbSU-88-17, PMSPbSU-88-18, PM-SPbSU-88-21， PM-SPbSU-88-31, PM-SPbSU-88-32);

- Pokayama Formation, Middle-Upper Famennian: in terrigenous sediments of deltaic sediment complex (sands, sandstones, siltstones, clays) (W slope of Northern Timan, middle course of Volonga River) - palaeosols with root systems - Callixylon zalesskyi (samples PM-SPbSU-88-15, PM-SPbSU-88-33, PMSPbSU-88-34, PM-SPbSU-88-35, PM-SPbSU-88-36, PM-SPbSU-88-37, PM-SPbSU-88-39), C. trifilievii (PM-SPbSU-88-27).

The material is kept in the Palaeontological Museum of St. Petersburg State University (PM$\mathrm{SPbSU}$, collections 88, 89, 96). We also worked with the type material of Callixylon trifilievii from the collections of M.D. Zalessky (TsNIGR Museum, St. Petersburg, collection 1415, and BIN RAS, St. Petersburg, collection 55).

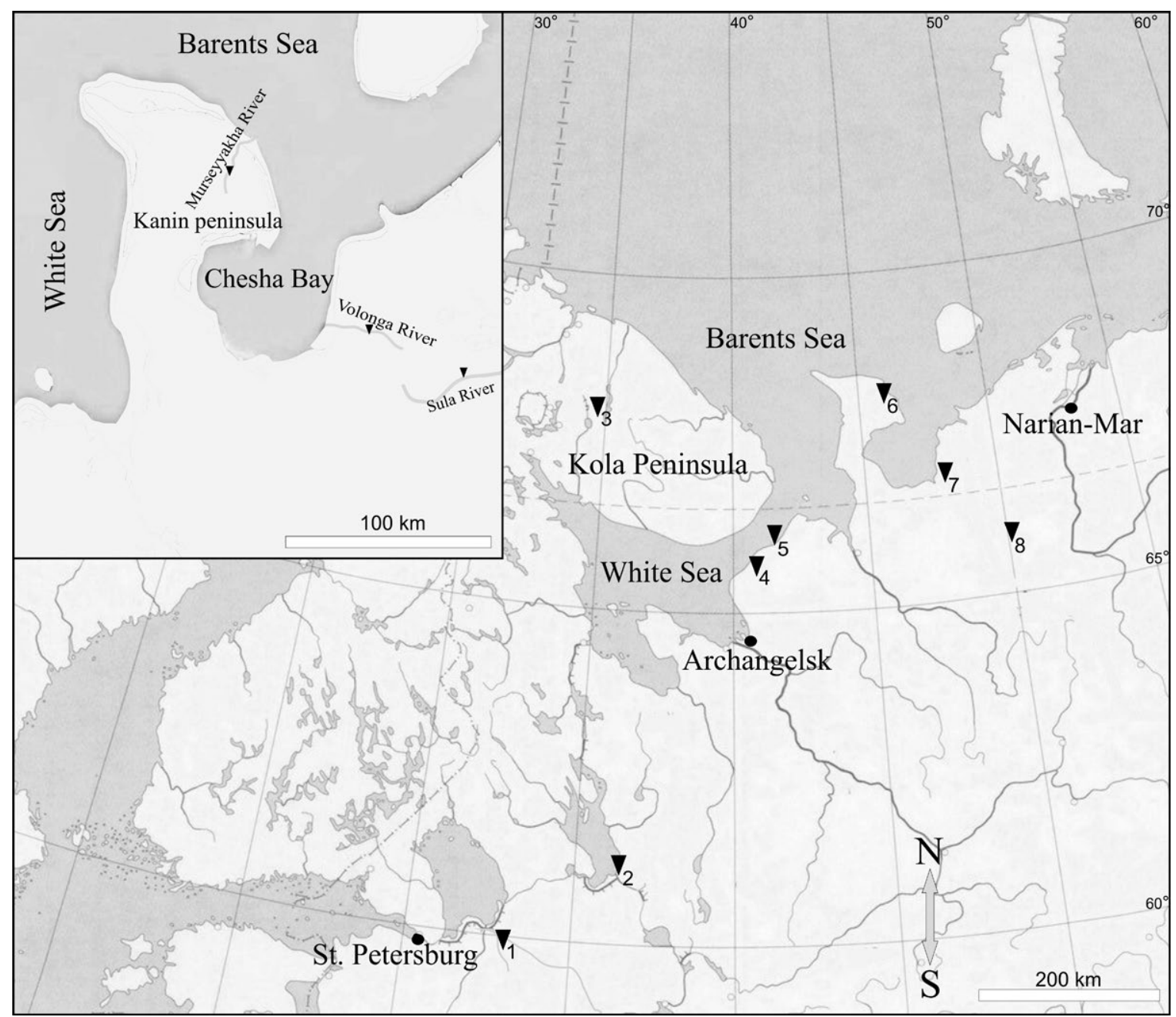

Fig. 1. Geographic position of the Late Devonian localities of the European part of Russia. 1 - River Syass, 2 - Andoma Mountain, 3 - Lovozero Massif, 4 - Lake Tovskoye, 5 - Zimniy Bereg (winter coast), 6 - Kanin Peninsula, 7 - Northern Timan, 8 - Middle Timan 


\section{DESCRIPTIONS OF FOSSIL WOOD}

\section{Callixylon trifilievii Zalessky, (1909) 1911}

Pl. 1, figs 1-7

A number of samples are fragments of coalified, pyritized or carbonized wood. The bestpreserved specimen consists of a $14 \mathrm{~mm}$ long and $3 \mathrm{~mm}$ wide axis.

In cross section fragments of the pith are preserved and consist of polyhedral cells $10-100 \mu \mathrm{m}$ in diameter (Pl. 1, fig. 1). There are several mesarch primary vascular bundles surrounding the pith. Phloem and cortex are absent. The secondary xylem tracheids are round and polygonal and do not exceed $40 \mu \mathrm{m}$ in diameter. Traces of periodic cambium activity were not found. Rays are uniseriate. Between them are $2-12$ rows of tracheid cells (Pl. 1, fig. 4).

In longitudinal (radial) section, pith cells are replaced by calcite crystals of elongated prismatic and bipyramidal habit. Tracheids of metaxylem are 10-30 $\mu \mathrm{m}$ in diameter and have secondary thickenings and flattened pits. A gradual transition from earlywood to latewood can be observed (Pl. 1, fig. 2). Secondary xylem tracheids are 15-40 $\mu \mathrm{m}$ in diameter. Cohortoid pitting is noticeable in tracheids of secondary xylem. Groups of 4-20 pits are arranged in 2-3 rows. Adjacent groups of pits are spaced 10-50 $\mu \mathrm{m}$ apart (19-20 $\mu \mathrm{m}$ on average) (Pl. 1, fig. 5). The pits are roundedhexagonal, averaging $10 \mu \mathrm{m}$ in diameter, with crossed apertures in pit pairs. The apertures of the pits are elongated, oblique, averaging $1 \times 8 \mu \mathrm{m}$ in size. Rays are $20-50 \mu \mathrm{m}$ wide, $1-7$ cells high. Ray tracheids are absent. The pits are arranged oppositely or alternately. In the cross-fields they are small, rounded, with 2-10 pits in one field (Pl. 1, fig. 6). The dimensions of the apertures coincide with the size of the apertures of the tracheid pits. Decomposition of cell walls occurs in some places. Here the wall surface is composed of oblique, sometimes dichotomous filaments (Pl. 1, figs 2, 3).

In longitudinal (tangential) section, low (1-10 cells high) uniseriate rays are observed (Pl. 1, fig. 7). The cells of the rays are wedgeshaped; on the tangential walls, pits are absent.

The comparisons rely on the revision by Orlova and Jurina (2011). Following the criteria outlined in that revision, we assign our material to the trifilievii group, distinguished by the presence of narrow (mostly uniseriate, less often double-rowed) rays and the absence of ray tracheids. The features presented by our sample are close to the first diagnosis of C. trifiievii Zalessky, given by Lemoigne et al. (1983). Our sample differs from other species of Callixylon having narrow rays (Tanrattana et al., 2019) by its heterocellular and thick-walled pith cells, and can be identified as $C$. trifiievii. Our specimens are too small to compare with the larger axes of this genus. The homologous rachis of Archaeopteris macilenta shows similar primary and secondary xylem arrangement (Carluccio et al., 1966: p. 724, fig. 16). However, a large percentage of the pith cells and the borders between pith and secondary xylem were destroyed by mineralization in our sample, so the pattern of bundle arrangement cannot be described.

Location, horizon: Representatives of this species are found ubiquitously in the Frasnian and Famennian deposits of North Timan. They were found along the banks of the Sula and Volonga rivers (and tributaries), as well as along the eastern coast of the Chesha Bay of the Barents Sea.

\section{Callixylon zalesskyi Arnold, 1930}

Pl. 2, figs 1-6, Pl. 3, figs 1-6

1930 Callixylon zalesskyi: Arnold, pp. 16-18; pl. IV, figs 1-3; pl. V, fig. 2.

1983 Callixylon zalesskyi: Lemoigne et al., p. 93, 94; pl. 10, figs 5-9.

2013 Callixylon zalesskyi: Decombeix, Meyer-Berthaud, p. 2220, 2223; fig. 20 G-J.

Specimens PM SPbSU 88/33-37 and 39 were selected from the palaeosol profile; they were buried in situ (Fig. 2A,B). This is a complex of subvertically buried wood remains; their nature and location indicate that they are most likely roots. Their morphology is similar to that of archaeopterid root casts reported by Algeo and Scheckler (1998: figs 3, 4c). The root structures are located in two subparallel rows spaced $\sim 1 \mathrm{~m}$ apart. In each row, the vertical "stumps" extending into the rock are spaced $30-60 \mathrm{~cm}$ apart. One row has five stumps and the other has three. The specimens consist of coalified wood fragments probably representing root parts. Further downstream, numerous vegetative shoots of Archaeopteris macilenta were found (Fig. 3). The cross section shows relatively frequent alternation of rays and tracheids; pith cells are absent. Uniseriate rays are separated by 2-10 rows of cells (average 2-5). Tracheid cells are rounded, 10-30 $\mu \mathrm{m}$ in diameter, sometimes filled with 

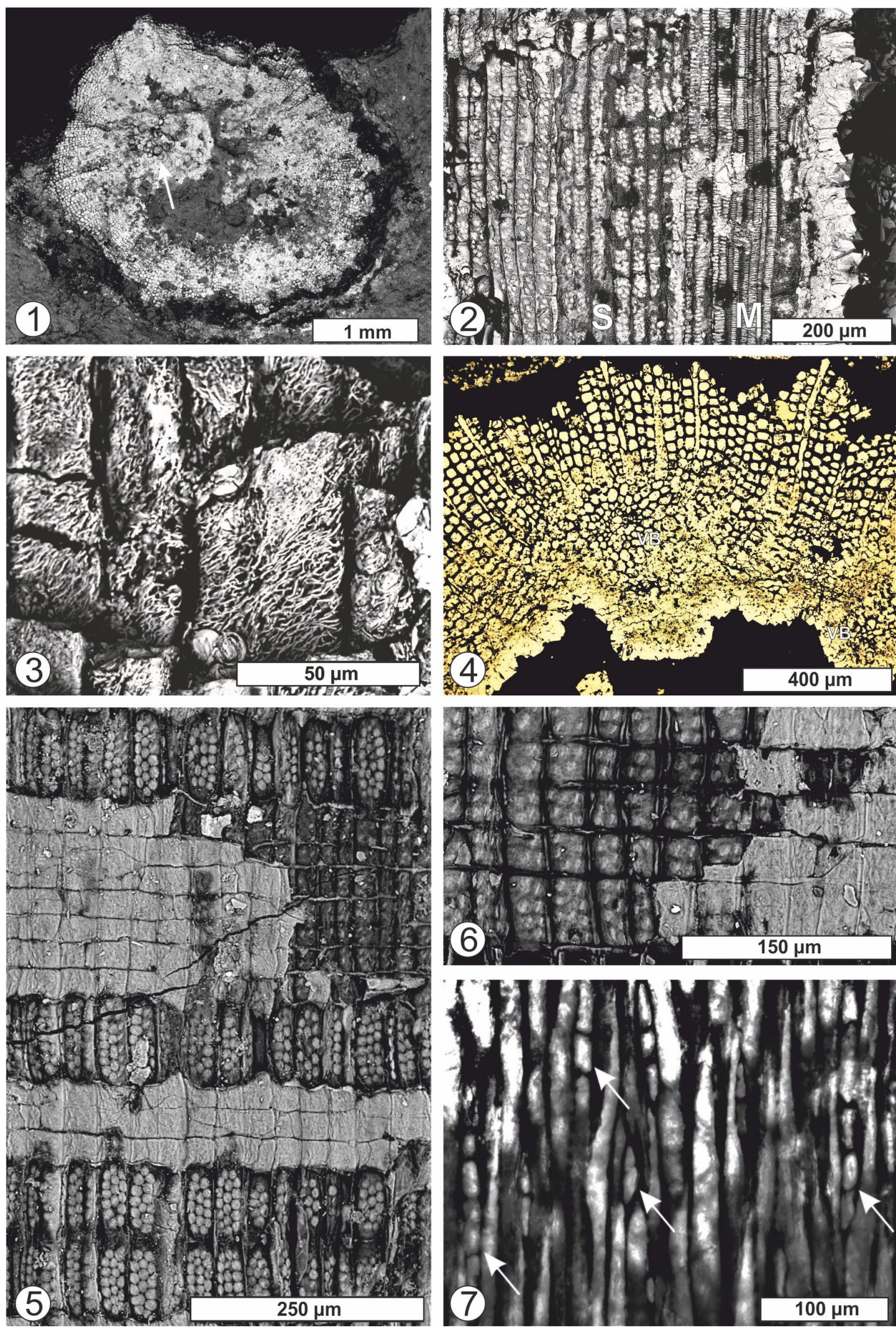

Plate 1. Callixylon trifilievii Zalessky, 1911. 1. Transverse view showing fragment of the pith (arrow) and secondary xylem. (Sample PM-SPbSU-88-27). 2. Longitudinal (radial) section. Transition from earlywood to latewood. Metaxylem with scalariform structure (M), secondary xylem (S). At left: cross-fields. Wall lysis processes (see fig. 3, magnified) destroyed the surface of secondary xylem cells (in middle of image) (Sample PM-SPbSU-88-27). 3. Longitudinal (radial) section. Decayed walls of tracheids, showing filiform structure caused by extensive lysis (see also fig. 2) (Sample PM-SPbSU-88-27). 4. Transversal section. Mesarch vascular bundles (VB) in connection with secondary wood (Sample PM-SPbSU-88-27). 5. Longitudinal (radial) section. Typical cohortoid pitting on radial walls of tracheids, and two rays (3 and 7 cells high) (Sample PM-SPbSU-88-27). 6. Longitudinal (radial) section. Rays (right) and pitted cross-fields (left) on radial walls of tracheids (Sample PM-SPbSU-88-27). 7. Longitudinal (tangential) section of secondary xylem with low uniseriate rays (arrows) (Sample PM-SPbSU-89-1) 

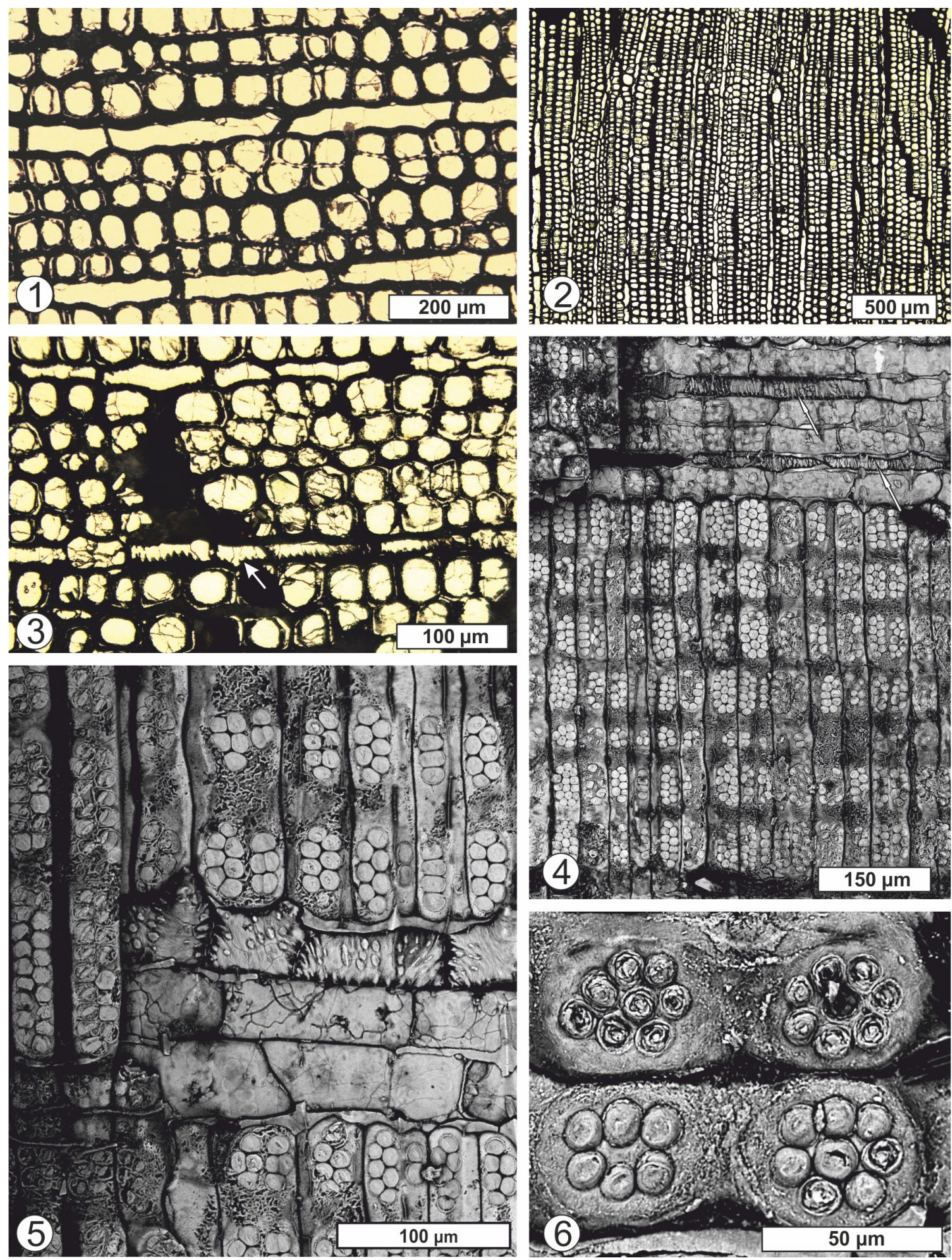

Plate 2. Callixylon zalesskyi. 1. Groups of pits binding tracheids (Sample PM-SPbSU-88-33). 2. Transverse section of secondary xylem, showing layer of tracheids with reduced radial diameter (Sample PM-SPbSU-88-33). 3. Transverse section. Ray tracheids of secondary xylem (arrow) (Sample PM-SPbSU-88-33). 4. Longitudinal (radial) section. Cohortoid pitting on radial walls of tracheids; at top, ray cells and ray tracheids (arrows - "rt") (Sample PM-SPbSU-88-33). 5. Longitudinal (radial) section. Cohortoid pitting on radial walls of tracheids; tracheid walls are destroyed in some places in middle of image (compare figs 2,3 ); ray 3 cells high, one of which is formed by ray tracheids, and two by ordinary cells of rays; numerous fungal hyphae (apparently recent ones) are visible on radial cells (Sample PM-SPbSU-88-33). 6. Longitudinal (radial) section. Altered pits on radial walls. Note the organization of some groups of pits: 6-7 pits around one central pit (Sample PM-SPbSU-88-36)

dark-colored substance. In places, pits binding tracheids are visible (Pl. 2, fig. 1). Ray cells are $10-40 \mu \mathrm{m}$ wide. There are narrow growth zones consisting of $4-5$ cell layers. The growth zones are indistinct, represented by thicker-walled tracheids, decreasing in diameter and expanding tangentially (Pl. 2, fig. 2). Small fragments of ray tracheids are rarely present ( $\mathrm{Pl} .2$, fig. 3 ).

In longitudinal (radial) section, only the structure of the secondary xylem was studied. 

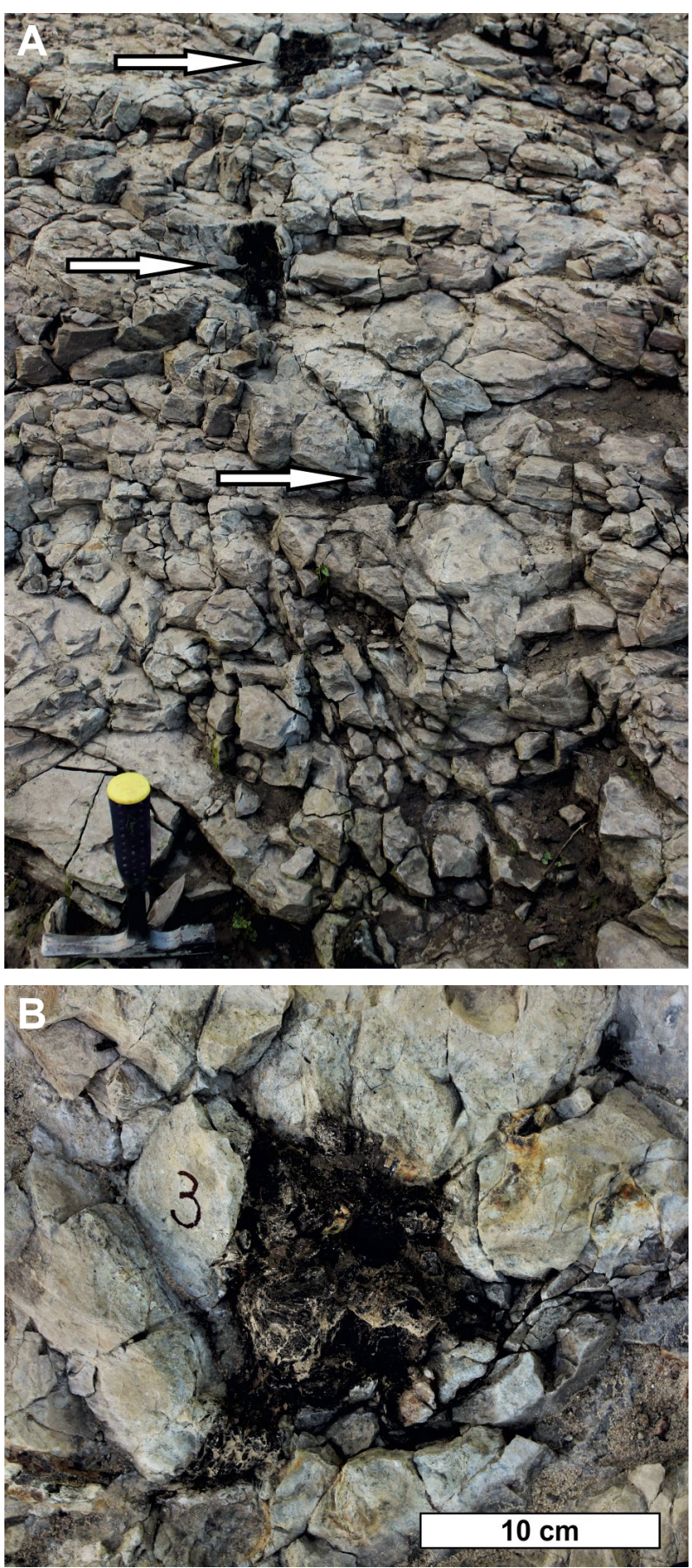

Fig. 2. A, B. Field photos of tree stumps preserved in siltstones (photo by P.A. Beznosov, Institute of Geology Komi SC UB RAS)

On the radial walls of tracheids, the pits are arranged in groups of 1 to 18. Pits are arranged in 1-3 rows. Adjacent groups are spaced 20-50 $\mu \mathrm{m}$ apart; in some areas up to $10 \mu \mathrm{m}$ in size the radial walls show no pits (Pl. 2, figs 4, 5). Tracheids of secondary xylem are 30-50 $\mu \mathrm{m}$ in diameter. Rounded pits $\sim 10 \mu \mathrm{m}$ in diameter have ellipsoid-oblique apertures. In one crossfield there are 3-6 pits with slit-like apertures (Pl. 3, fig. 1). In places there are groups of pits with modified apertures, becoming rounder or degraded. Some groups have 6-7 pits around 1 central pit (Pl. 2, fig. 6) (cf. Lemoigne et al., 1983: pl. 4, fig. 3). The rays vary from 1 to 24 cells in height. Often there are ray tracheids with small pits $(1-5 \mu \mathrm{m})$ and oblique apertures. Radial tracheids vary from 40 to $120 \mu \mathrm{m}$ in length (Pl. 2, figs 3-5; Pl. 3, fig. 1).

Filiform structures penetrating the tracheids and filling the intercellular space were encountered in many samples. Hyphae of fungi are abundant in both tracheids and ray cells, frequently oriented parallel to the long axis of the infected cell. Hyphae range from 1 to $5 \mu \mathrm{m}$ in diameter. Branched hyphae are frequent, sometimes intertwined inside infected cells (Pl. 2, fig. 5). Due to the fragmentary nature of the material, the true extent of fungal infection cannot be determined. This requires additional study.

In longitudinal (tangential) section within one sample there is noticeable variability of ray size, and chaotic arrangement of numerous uniseriate and multiseriate rays. The height of rays ranges from 50 to $900 \mu \mathrm{m}$, from 2 to 20 cells (Pl. 3, figs 2, 3). Exceptionally large rays are found; they may have been formed by the merging of cells that degraded during fossilization or during the life of the plant. The cavity of these rays is filled with a solid substance (Pl. 3, fig. 3), but fragments of destroyed cells are visible on the margin of the cell walls (Pl. 3, fig. 5). Tangential walls of tracheids are pitted. The tangential pits are small, $10 \mu \mathrm{m}$ in diameter. They are round, numerous, randomly

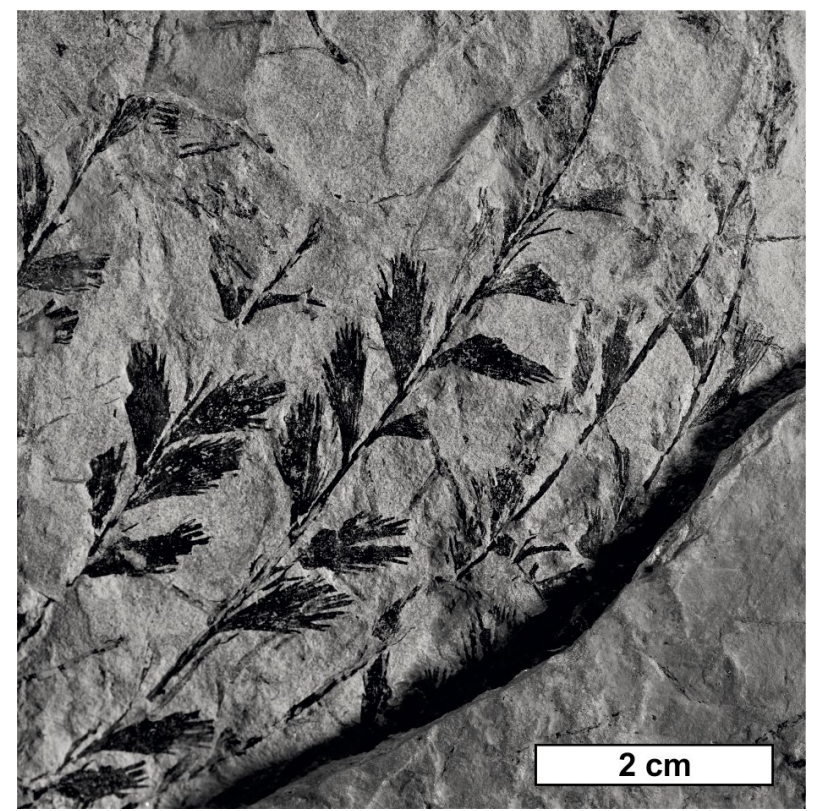

Fig. 3. Vegetative shoot of Archaeopteris macilenta 

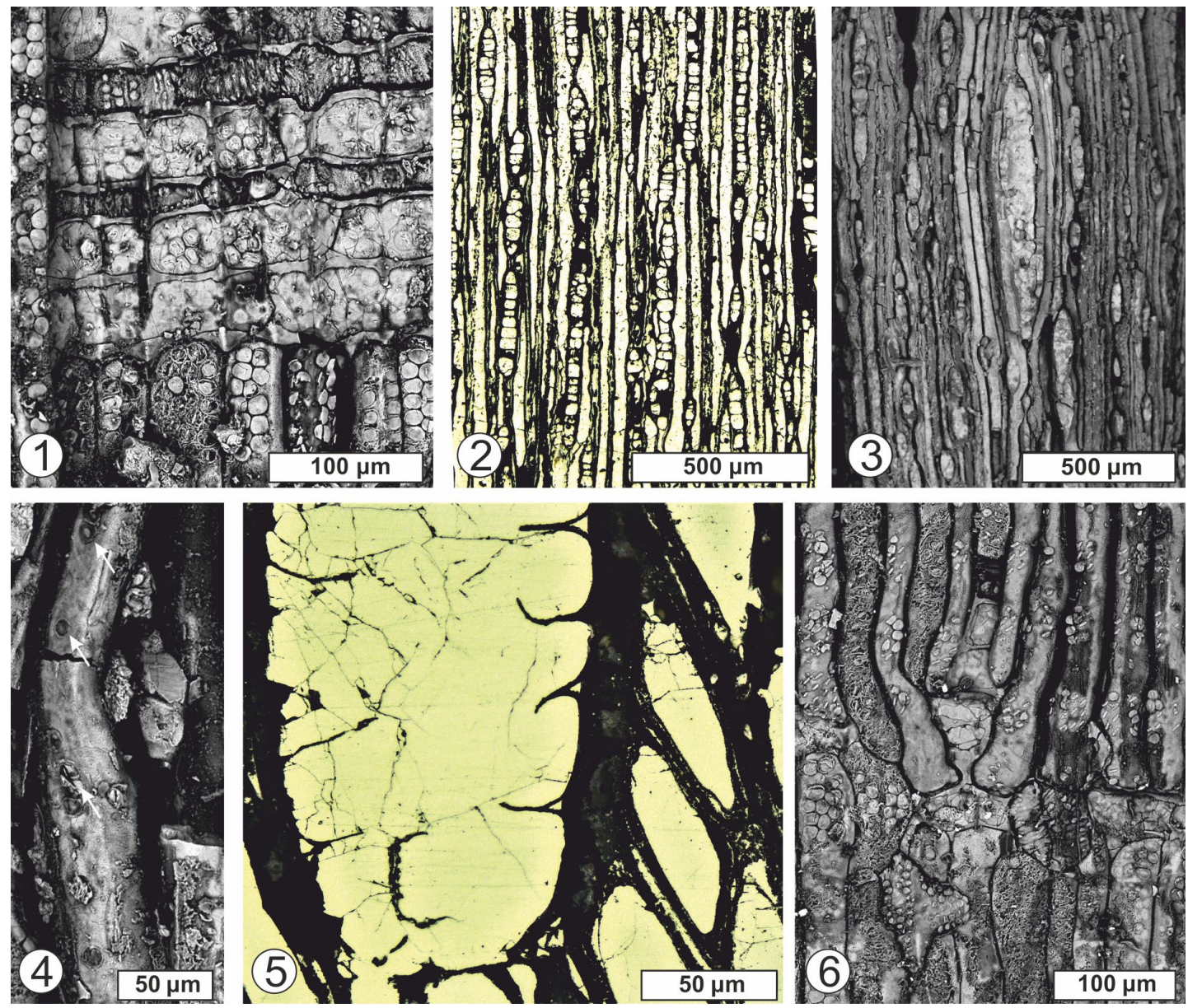

Plate 3. Callixylon zalesskyi. 1. Longitudinal (radial) section. Cells of rays, ray tracheids and cross-fields. Note that walls of both ray tracheids and tracheids (but not ray cells) are damaged by lysis (Sample PM-SPbSU-88-33). 2. Longitudinal (tangential) section. Numerous high rays arranged irregularly (compare fig. 3) (Sample PM-SPbSU-88-36). 3. Longitudinal (tangential) section. Numerous low rays arranged irregularly (compare fig. 2). A large ray consisting of several fused cells in middle part of image (Sample PM-SPbSU-88-33). 4. Longitudinal (tangential) section. Tracheid with pits (arrows) on tangential wall (Sample PM-SPbSU-88-33). 5. Longitudinal (tangential) section. Enlarged ray with preserved fragments of destroyed cells that formed the ray (Sample PM-SPbSU-88-33). 6. Longitudinal (radial) section. Region of tracheid closure and altered ray tracheids (Sample PM-SPbSU-88-33)

distributed 40-80 $\mu \mathrm{m}$ apart, and not grouped (Pl. 3, fig. 4).

Comparisons: In view of the presence of ray tracheids in the described wood, it can be attributed to the erianum group of the genus Callixylon (Orlova and Jurina, 2011; Tanrattana et al., 2019). Previously we identified the wood remains as Callixylon aff. newberryi, but after discussions with the reviewers we lean toward identification of the material as C. zalesskyi. The growth zones found in our material are very similar to those of C. zalesskyi (cf. our Pl. 2, fig. 2 and fig. $2 \mathrm{G}$ in Tanrattana et al., 2019). The essential distinguishing feature of the described material, which we did not find in other species of this genus, is the presence of especially large rays ( $\mathrm{Pl}$. 3, fig. 3 ). They are very similar to the broad rays described in C. mentethense Arnold, 1930. We suggest that the large ray size is related to the fact that the material consists of roots. Anatomically preserved root specimens corresponding to erianum types of Callixylon wood were described from a marine deposit of Famennian age in southeastern Morocco; they provided the first direct evidence of the growth potential and complex architecture of the root system in Archaeopterids (Meyer-Berthaud et al., 2013). Enlarged rays and other alterations could also be caused by deformation of root structures in vivo. The fossil-bearing layer contains a fault overlapped by a layer of clay siltstones, without evidence of sediment movement. Probably this is the result of the formation of cracks in previously unconsolidated sediment. The underground axes of Callixylon that were widespread in paleosols could have been disturbed as a result of minor ground movement. It is possible that the structure (shown in Pl. 3, fig. 6) was formed as a result of the same traumatic events. In general, it should be noted 

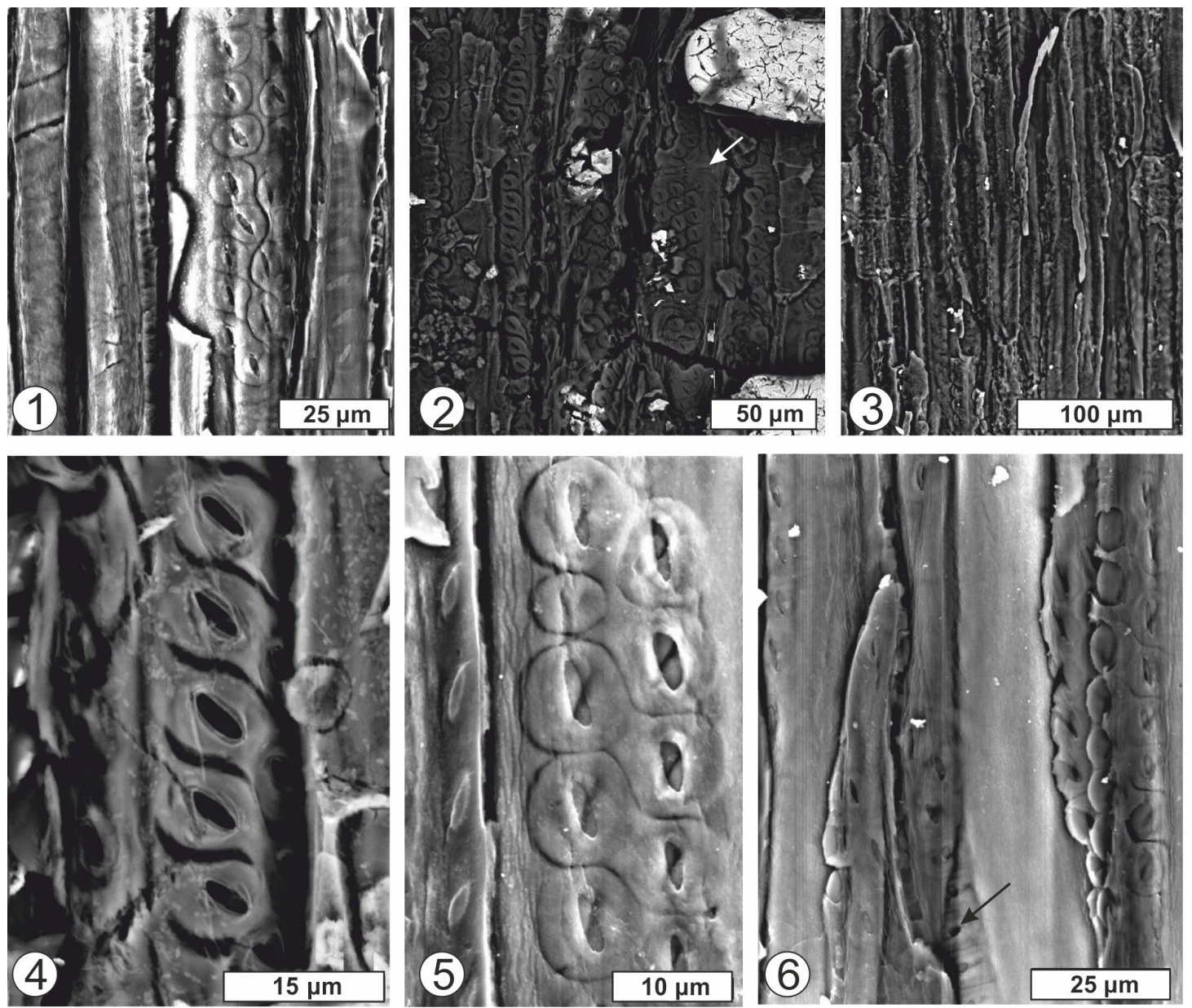

Plate 4. Callixylon sp. 1, 2, 3. Longitudinal (radial) section. Cohortoid type of pitting in secondary xylem. Trabeculae (T, arrow) on radial walls of tracheids (Pl. 3, fig. 6) (Samples PM-SPbSU-96-86, PM-SPbSU-88-18, PM-SPbSU-89-3). 4. Longitudinal (radial) section. Oblique apertures in bordered pits (Sample PM-SPbSU-88-18). 5. Longitudinal (radial) section. Intersecting apertures and small undeveloped pit (Sample PM-SPbSU-96-86). 6. Longitudinal (radial) section. Round apertures in bordered pits (arrow) (Sample PM-SPbSU-96-86)

that some samples of various Callixylon species show such structures: very large rays, or groups of tracheids, merged together and well visible in cross section (see also Lemoigne et al., 1983: pl. 2, fig. 8).

Location, horizon: Numerous fragments of root systems were found in sediments of the Pokajama Formation (Upper Frasnian) on the right bank of the Volonga River.

\section{Callixylon sp.}

Pl. 4, figs 1-6, Pl. 5, figs 1-5

The preservation of the samples allows only fragmentary study of them. The wood is highly coalified and splits into single tracheids or groups of them after drying.

On the radial cleavage surface, tracheids of the secondary xylem are $25-40 \mu \mathrm{m}$ in diameter, with rounded endings. The type of pitting is similar to that of Callixylon. Pits form clusters of up to 19 pits in a group; they are commonly contiguous, rarely separate, and are alternate, subopposite, and rarely opposite, sometimes fused (Pl. 4, figs 1-3). Pits are up to $10 \mu \mathrm{m}$ in diameter, with oblique apertures, sometimes intersecting, sometimes oriented in one direction (Pl. 4, figs 4,5). Smaller pits without apertures, probably undeveloped, were seen in the groups (Pl. 4, fig. 5). Sometimes the apertures are round, up to $2 \mu \mathrm{m}$ in diameter (Pl. 4, fig. 6). There are trabeculae - small transverse outgrowths of the cell membrane that pass through the cavity of the tracheids from one tangential wall to another (Pl. 4, fig. 1). The rays are very poorly preserved; sometimes they are seen to be simple, uniseriate, $40-60 \mu \mathrm{m}$ in diameter; ray tracheids are not found (Pl. 4, fig. 1; Pl. 5, fig. 5). The pitting type of cross-fields is cupressoid, round, bordered pits with narrow apertures that do not reach the borders (Pl. 5, fig. 1). Spiral thickenings are arranged horizontally on the radial walls ( $\mathrm{Pl}$. 5, figs 2,3 ). In some places the ray 


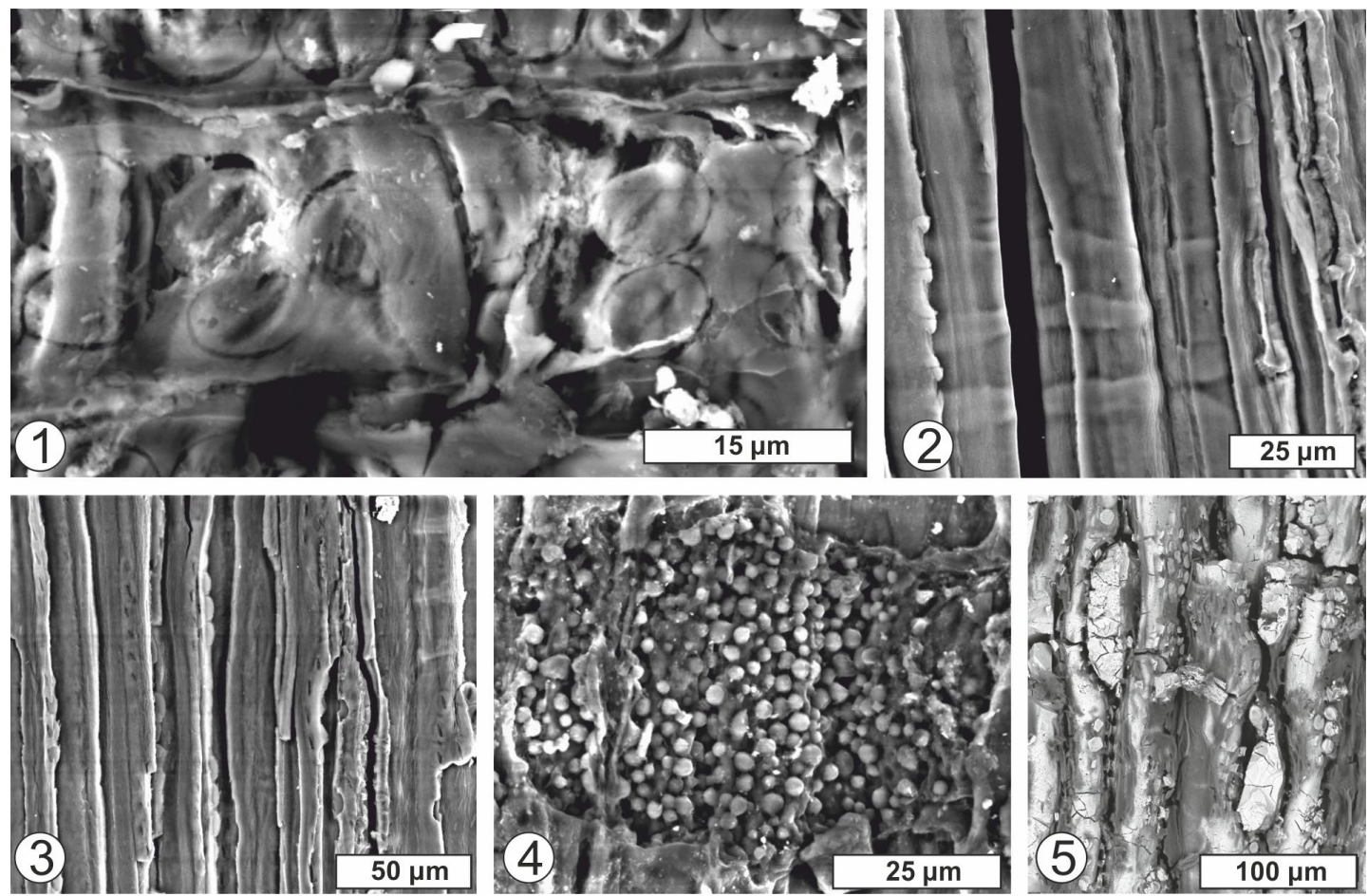

Plate 5. Callixylon sp. 1. Longitudinal (radial) section. Cupressoid pitting of cross-fields (Sample PM-SPbSU-88-18). 2. Longitudinal (radial) section. Thickenings on radial walls (magnified) (Sample PM-SPbSU-96-86). 3. Longitudinal (radial) section. Thickenings on radial walls arranged horizontally (at top right) (Sample PM-SPbSU-96-86). 4. Longitudinal (radial) section. Globular formations in ray cell (Sample PM-SPbSU-96-1). 5. Longitudinal (tangential) section. Low uniseriate rays (Sample PM-SPbSU-88-18)

cells are filled with globular bodies $2.5-3 \mu \mathrm{m}$ in diameter (Pl. 5, fig. 4).

On the tangential cleavage surface the rays are low (1-2 cells high); the tangential walls of the tracheids are not pitted (Pl. 5, fig. 5).

Location, horizon: Remains of coalified, strongly modified Callixylon sp. wood were found in Lower Frasnian sediments from the Sula River and from the Kanin Peninsula, as well as in Middle-Upper Frasnian deposits along the eastern coast of Chesha Bay.

\section{DISCUSSION}

One species of C. trifilievii wood and two significantly different types of leafy branches are currently known: Archaeopteris archetypus and A. fissilis from the type locality of Callixylon in the Donetz Basin. Both of these Archaeopteris species are widespread in Upper Devonian sediments of Northern Timan, and most likely one of these species possessed C. trifilievii wood.

Here we reported the first finding of C. zalesskyi in Northern Timan; apparently it represents part of the root system or the most basal parts of the stem.

When Beck (1960) established that Callixylon and Archaeopteris are identical, he indicated that the foliage of $A$. macilenta corresponds to wood of the type C. zalesskyi. It is noteworthy that monospecific burials of Archaeopteris macilenta were found in isolated layers of gray sandstone and siltstone on the Volonga River, where C. zalesskyi was found. These data may be important for identifying and correlating various formal species. The finding of C. zalesskyi in association with the remains of Archaeopteris macilenta foliage is the first in the European part of ancient Euramerica.

The features of wood decay seen in our material from Northern Timan and the Kanin Peninsula could be signs of the kind of activity characteristic of modern basidomycetes, causative agents of rotting (Stubblefield et al., 1985: figs 11, 16, 18; compare with our Pl. 5, fig. 4). The globular bodies filling the ray cells presumably are the result of bacteriological activity in the dead wood.

Taylor and Osborn (1996: p. 253) noted that "wood-rotting fungi selectively destroy cellulose and lignin at different rates" and gave examples of erosion troughs in the secondary wall of a tracheid in Callixylon wood (Taylor and Osborn, 1996: pl. I, fig. 2). The same type of destruction (lysis) of tracheid walls is observed on our material, shown in our Plate 2, figures 4 and 5, and Plate 3, figure 1. Fungal hypha penetrating the 
wall of a tracheid (Taylor and Osborn, 1996: pl. I, fig. 5) are very close to those in our Plate 2, figure 5. They may indicate saprophytic activity.

However, both the Timanian material and samples described by Taylor and Osborn (1996) and Stubblefield et al. (1985) are not unequivocally the remains of Devonian fungi. The similarity of the kind of destruction in structures of Callixylon wood from the USA and Russia suggests that these structures formed under similar conditions. In view of the position of the wood in the section, and their morphology, it cannot be excluded that the fungi are mycorrhizal.

\section{CONCLUSIONS}

During the Devonian the first forest ecosystems became widespread around the world (Mintz et al., 2010; Stein et al., 2012; Giesen and Berry, 2013; Berry and Marshall, 2015; Wang et al., 2019). The data presented in this paper provide evidence of the wide distribution of forest-forming plants of the Late Devonian Archaeopteridophyta - over vast areas located at present in the Arctic zone of northern Russia. Timan Ridge and the Kanin Peninsula were sites of the active development of the Earth's first forests, which created the basis for further terrestrialization processes (Beznosov et al., 2018a).

\section{ACKNOWLEDGEMENTS}

We are grateful to the employees of VSEGEI (D.V. Zarkhidze, A.V. Krylov, A.E. Tsybulskaya, L. Bogatyrev, M.A. Pavlova) and P.A. Beznosov, who made it possible for us to collect Devonian fossil wood in Northern Timan and the Kanin Peninsula and who helped much with fieldwork, and B. Meyer-Berthaud, P. Gerrienne, C. Berry, D.V. Gromyko, M. Afonin, J. Bogdanova and two reviewers of the article for fruitful discussions of the material and for helpful advice. The opportunity to study microstructure was provided by the Research Park of St. Petersburg State University (RC "X-ray diffraction methods" and RC "Microscopy and Microanalysis", both SPbSU).

The work was carried out as part of St. Petersburg State University initiative project no. 3.52.908.2017: "Study of the Devonian floras (fossil plants) of Northern Timan: taphonomy, palaeoecology, evolutionary significance".

\section{REFERENCES}

Algeo, T.J., Scheckler, S.E., 1998. Terrestrial-marine teleconnections in the Devonian: links between the evolution of land plants, weathering processes, and marine anoxic events. In: Beerling, D.J., Chaloner, W.G., Woodward, F.I. (eds), Vegetation-climateatmosphere interactions: past, present and future. Philosophical Transactions of the Royal Society of London, Ser. B 353(1365), 113-130.

Antashtchuk, M.G., Snigirevsky, S.M., 2003. Ustanovlenije vizejskikh otlozhenij $\mathrm{v}$ zone sochlenenija Russkoj platformy i Baltijskogo shchita (Arkhangel'skaja obl.): paleobotanitcheskoje obosnovanije (summary: Visean sediments in the contact zone of Russian platform and Baltic shield (Arkhangelsk region): paleobotanical evidences). Vestnik of Saint Petersburg University, ser. 7, geologija, geographia 2(15), 94-101.

Arnold, C.A., 1930. The genus Callixylon from the Upper Devonian of Central and Western New York. Papers of the Michigan Academy of Sciences, Arts and letters 11, 1-50.

Beck, C.B., 1960. The identity of Archaeopteris and Callixylon. Brittonia 12(4), 351-368.

Berry, C.M., Marshall, J.E.A., 2015. Lycopsid forests in the early Late Devonian paleoequatorial zone of Svalbard. Geology 43, 1043-1046.

Beznosov, P., 2018. Biomineral'nyje obrazovanija v koprolitakh iz kumushkinskoj svity verkhnego devona Severnogo Timana (Biomineral structures in coprolites from the Upper Devonian Kumushka Formation of North Timan). Modern problems of theoretical, experimental, and applied mineralogy (Yushkin Memorial Seminar - 2018); Proceedings of mineralogical seminar with international participation Syktyvkar, Komi Republic, Russia 22-24, May 2018, 151-152.

Beznosov, P., Mantsurova, V., Lukševičs, E., 2014. Vertebrate and miospore assemblages from the Famennian of North Timan (Upper Devonian, Russia). In: Rocha, R. et al. (eds), STRATI 2013. Springer Geology, XLV, pp. 469-473.

Beznosov, P., Lukševičs, E., Ahlberg, P.E., 2017. Vertebrate assemblages from the Famennian (Upper Devonian) of North Timan (Russia). In: Żylińska, A. (ed.), $10^{\text {th }}$ Baltic Stratigraphic Conference, Chęciny, 12-14 Sept. 2017. Abstracts and Field Guide. University of Warsaw, Warszawa, pp. 19-20.

Beznosov, P.A., Snigirevsky, S.M., Naugolnykh, S.V., Lukševičs, E., 2018a. Verkhnedevonskij kompleks otlozhenij del'tovoj ravniny na Severnom Timane (summary: The Upper Devonian delta plain deposits of North Timan). Vestnik Instituta Geologii Komi Nauchnogo Tsentra UB RAS, 1, 25-44.

Beznosov, P.A., Snigirevsky, S.M., Naugolnykh, S.V., Lukševičs, E., 2018b. Famenskaja biota Severnogo Timana (Famennian biota of North Timan). Proc. of the Palaeontol. Soc., I, 15-22.

Bussen, I.V., Petrosjan, N.M, Sakharov, Ja.D., 1969. Novyje dannyje o vozraste lovozerskoj osadochnovulkanogennoj svity (Kol'skij poluostrov) (New data of the age of the Lovozersk sedimentary-igneous rock series (the Kola peninsula). Doklady AN SSSR 188(1), 170-172. 
Carluccio, L.M., Hueber, F.M., Banks, H.P., 1966. Archaeopteris macilenta, Anatomy and Morphology of Its Frond. American Journal of Botany 53(7), 719-730.

Coulon, M., Lemoigne, Y., 1969. Palaeoxylon bourbachensis, nouvelle structure ligneuse du Viséen des Vosges. Comptes Rendus de l'Académie des Sciences Paris, Ser. D, 269(16), 1498-1501.

Decombeix, A.-L., Meyer-Berthaud, B., 2013. A Callixylon (Archaeopteridaceae, Progymnospermopsida) trunk with preserved secondary phloem from the Late Devonian of Morocco. American Journal of Botany 100(11), 2219-2230.

Galtier, J., Schneider, J.-L., Grauvogel-Stamm, L., 1998. Arborescent gymnosperms and the occurrence of Protopitys from the Lower Carboniferous of the Vosges, France. Review of Palaeobotany and Palynology 99(3-4), 203-215.

Giesen, P., Berry, C.M., 2013. Reconstruction and growth of the early tree Calamophyton (Pseudosporochnales, Cladoxylopsida) based on exceptionally complete specimens from Lindlar, Germany (Mid Devonian): organic connection of Calamophyton branches and Duisbergia trunks. International Journal of Plant Sciences 174, 665-686.

Kryshtofovich, A.N., 1937. Verkhnedevonskije rastenija iz severo-vostochnoj chaste Lovozerskikh tundr Kol'skogo poluostrova (Upper Devonian plants of the Kola Peninsula). Bulletin de l'Academie des Science de l'URSS, Cl. des Sci. Mat. et Natur.; ser. Geol. 4, 691-699.

Lemoigne, Y., Zdebska, D., 1980. Structures problematiques observées dans des axes provenant du chert dévonien de Rhynie. Acta Palaeobotanica 21(1), 3-8.

Lemoigne, Y., Iurina, A., Snigirevskaya, N., 1983. Revision du genre Callixylon Zalessky, 1911 (Archaeopteris) du Devonien. Palaeontographica, Abt. B 186(4/6), 81-120.

Lepechina, V.G., 1968. Novyj pozdnedevonskij prapaporotnik (New Late Devonian prefern). In: Markovsky, B.P. (ed.), Novyje vidy drevnikh rastenij i bespozvonochnykh SSSR, II(I), pp. 37-40.

Meyer-Berthaud, B., Decombeix, A.L., Ermacora, X., 2013. Archaeopterid root anatomy and architecture: new information from perminelized specimens of Fammenian age from Anti-Atlas (Morocco). International Journal of Plant Sciences 174(3), 364-381.

Mintz, J., Driese, S.G., White, J.D., 2010. Environmental and ecological variability of Middle Devonian (Givetian) forests in Appalachian Basin paleosols, New York, United States. Palaios 25, 85-96.

Orlova, O.A., 2007. Early Carboniferous plants of the Arkhangelsk Region, Russia. Paleontological Journal 41(11), 1138-1150.

Orlova, O.A., 2009. A new fossil wood (Lyginopteridophyta?) from the Lower Carboniferous of the Arkhangelsk region. Paleontological Journal 43(5), 584-588.

Orlova, O.A., Jurina, A.L., 2011. Genus Callixylon Zalessky (Archaeopteridophyta): Main criteria for distinguishing its species and revision of its species composition. Paleontological Journal 45(5), 580-589.

Orlova, O.A., Jurina, A.L., Alekseev, A.S., Lisitsyn, A.Ja., Larchenko, V.A., Minchenko, G.V., Stepanov, V.P., 2004. Pervaja nakhodka rannekamennougol'noj flory na Belomorsko-Kulojskom plato, Arkhangel'skaja oblast' (rajon oz. Tovskoje) (The first discovery of the Early Carboniferous flora on the White Sea-Kuloi Plateau, Arkhangelsk Region (Lake Tovskoye area). Paleostrat 2004, 24-25.

Orlova, O.A., Jurina, A.L., Gordenko, N.V., 2011. O pervoj nakhodke drevesiny archeopterisovykh $\mathrm{v}$ verkhnedevonskikh otlozhenijakh Srednego Timana (First finding of Archaeopteridaceae Wood in the Upper Devonian Deposits of the Middle Timan Region). Moscow University Geology Bulletin 66(5), 341-347.

Orlova, O.A., Jurina, A.L., Snigirevsky, S.M., 2016. Late Devonian plant communities of North Russia. Review of Palaeobotany and Palynology 224(1), 94-107.

Snigirevskaya, N.S., 2012. Znachenije paleobotanicheskogo analiza detrita $\mathrm{v}$ zherlakh vulkanicheskikh trubok (Arkhangel'skaja oblast', Rossia) (summary: The importance of the palaeobotanical analysis of detritus inside volcanic pipe craters (the Arkhangelsk region, Russia). Botanicheskii Zhurnal 97(11), 1459-1471.

Snigirevskaya, N.S., Snigirevsky, S.M., 2001. New locality of Callixylon (Archaeopteridaceae) in the Upper Devonian of Andoma mountain (Vologda district, North-West of Russia) and its importance for the reconstruction of Archaeopterids distribution. Acta Palaeobotanica 41(2), 97-105.

Snigirevsky, S.M., 1997. Pozdnedevonskaja flora Severnogo Timana (Late Devonian flora of Northern Timan). PhD Thesis, St. Petersburg State University, pp. 1-16.

Snigirevsky, S.M., Tschibrikova, E.V., Olli, V.A., 2007. Fossil plants with spores in the sporangia from the Upper Devonian (Frasnian) deposits of Northern Timan. Paleontological Journal 41(4), 461-468.

Soria, A., Meyer-Berthaud, B., 2005. Reconstructing the Late Devonian Cladoxylopsid Pietzschia schulleri from new specimens from Southeastern Morocco. International Journal of Plant Science 166(5), 857-874.

Stein, W.E., Berry, C.M., Hernick, L.V., Mannolini, F., 2012. Surprisingly complex community discovered in the mid-Devonian fossil forest at Gilboa. Nature 483, 78-81.

Stubblefield, S.P., Taylor, T.N., Beck, C.B., 1985. Studies of Paleozoic Fungi. IV. Wood-decaying Fungi in Callixylon newberryi from the Upper Devonian. American Journal of Botany 72(11), 1765-1774.

Tanrattana, M., Meyer-Berthaud, B., Decombeix, A.-L., 2019 (for 2017). Callixylon wendtii sp. nov., a new species of archaeopteridalean progymnosperm from the Late Devonian of Anti-Atlas, Morocco. Earth and Environmental Science Transactions of The Royal Society of Edinburgh 108, 373-385. 
Taylor, T.N., Osborn, J.M., 1996. The importance of fungi in shaping the paleoecosystem. Review of Palaeobotany and Palynology 90(3-4), 249-262.

Wang, D., Qin, M., Liu, L., Liu, L., Zhou, Y., Zhang, Y., Huang, P., Xue, J., Zhang, S., Meng, M., 2019. The most extensive Devonian fossil forest with small lycospid trees bearing the earliest stigmarian roots. Current Biology 29, 2604-2615.

Zalessky, M.D. (Zalesskij), 1909. Communication préliminaire sur un nouveau Dadoxylon à faisceaux de bois primaire autour de la moelle, provenant du dévonien supérieur du bassin du Donetz.Bulletin de l'Académie impériale des sciences de St.-Pétersbourg., VI Sér., III(18), 1175-1178.
Zalessky, M.D., 1910. Soobshchenije o novoj forme Dadoxylon s puchkami pervichnoj ksilemy vokrug serdtseviny iz verkhnedevonskikh osadkov Donetskogo bassejna (Report on a new form of Dadoxylon with bundles of primary xylem around the pith of the Upper Devonian sediments of the Donets Basin). Bull. Soc. Imp. des Naturalistes de Moscou, Annee 1909, Appendices to the protocols, 52-55.

Zalessky, M.D., 1911. Étude sur l’anatomie du Dadoxylon Tchihatcheffi Göppert sp. Mémoires du Comité géologique, Nouv. Ser. 68, 1-29. 